Social Work кринццьк, I. (2019). Планууання о організапія \& Education соціальної роботи з маргіналізованими групами. Social Work and Education. Vol. 6, No. 3. Ternopil-Aberdeen, $2019 . \quad$ pp. 249-258. ๑) SW\&E, 2019 DOI: $10.25128 / 2520-6230.19 .3 .3$

УДК 316.4

DOI: $10.25128 / 2520-6230.19 .3 .3$

\section{ПЛАНУВАННЯ І ОРГАНІЗАЦІЯ СОЦІАЛЬНОЇ РОБОТИ 3 МАРГІНАЛІЗОВАНИМИ ГРУПАМИ}

\section{Ірина Криницька,}

кандидат сочіологічних наук, доиент кафедри соичіальної педагогіки,

Львівський католицький університет, м.Львів, Україна krynytska@ucu.edu.ua
Article history:

Received: March 20, 2019

1st Revision: July 29, 2019

Accepted: September 30, 2019
АНОТАЦІЯ. В доповіді визначений підхід до організації соціальної роботи із маргіналізованими групами. Розглянуто поняття маргіналізації. За основне теоретичне підгрунтя у здійсненні соціальних досліджень маргіналізованих груп взято до уваги теорію соціальних проблем, теорію змін, теорію мотивації, соціального включення i виключення. Виокремлено основні чинники внутрішніх $\mathrm{i}$ зовнішніх змін. Запропоновано базові процеси для початкового рівня соціальної роботи 3 маргіналізованими групами. Визначено рівні підтримки соціальної роботи 3 цими категоріями на макро-, мезо- i мікрорівнях суспільства. Запропоновано напрями організаційної роботи фахівців із маргіналізованими групами.

Ключові слова: маргіналізація; соціальна робота; теорія змін; соціальне виключення; рівні підтримки соціальної роботи; напрями організаційної роботи. 


\section{Вступ}

Розвиток українського суспільства сьогодні грунтується назасадах регуляції актуальних сучасних проблем. Україна проголосила себе соціальною державною і зобов'язалася забезпечити соціальний захист різних груп населення. Безумовно, сьогодні однією з основних проблем суспільства є війна на Сході України, яка спричинила нові соціальні виклики, такі як: соціальне забезпечення і соціальна адаптація внутрішньопереміщених осіб, адаптація військовослужбовців і членів ïx сімей до нових викликів щоденного життя. Проте надалі актуальним залишається питання соціального становища i соціального включення осіб ромської національності, осіб, які повернулися з місць позбавлення волі, осіб, які мають ВІЛ/СНІД-позитивний статус та інших, на що будуть спрямовані подальші наукові пошуки.Постійне існування цих категорій у площині соціальних проблем створила серед них явище «соціального виключення» i маргіналізації. На запобігання та профілактику такого становища сьогодні має бути спрямована діяльність соціальної політики в Україні.

Якщо сфера соціального захисту в еквіваленті матеріального забезпечення вразливих категорій населення поступово вибудовується в сталий рівень, то проблема їхньої стигматизації, маргіналізації та соціального виключення $\epsilon$ невирішеною. Сучасні реалії свідчать про наявність проблеми працевлаштування i низький рівень активного соціального життя цих категорій населення, що спричинює їхнє соціальне відчуження. Жодна із соціальних установ активно не займається вирішенням цих питань. Сьогодні є потреба організувати якісне надання соціальних послуг, створити систему відповідальних інституцій, особливо це актуально в контексті реформи децентралізації і налагодження активної роботи з громадами і в громадах на локальному рівні.

Маргінальність була розглянута у працях Т. Веблена, Х. Кріслатої,Л. Лінгур, О. Литвинчук, Р. Парка, С. Поліщука, С. Ципко,та ін. У розробці програм соціальних досліджень маргіналізованих груп вважаємо за потрібне взяти до уваги теорію соціальних проблем (Г. Блумер, Дж. Кітсюз,Р. Майерс, С. Спектор, Р. Фуллер), теорію позитивних змін (Г. Блюм,Ї. Прохазка) теорію змін (К. Левін) та теорію мотивації (К. Альдефер, Л. Виготський, А. Маслоу та ін.), соціальноговключення та соціального виключення.

Mema cmammi - основним дослідним питанням є організація ефективної системи та визначення чітких напрямів здійснення соціальної роботи із маргіналізованими категоріями та групами, що має стати пріоритетом у соціальній політиці в Україні.В межах цієї праці буде окреслений підхід до організації соціальної роботи із маргіналізованими групами для створення платформи формування базових чинників змін. 


\section{Методологія дослідження}

У контексті дослідження ми: використовували загальнонаукові методи синтезу, аналізу, порівняння й узагальнення; здійснювали пошук інформації, аналізували повнотекстові наукові праці, розміщенні у наукометричній базі Google Scholar.

\section{Основна частина}

Соціальні проблеми для своєї ідентифікації в площині соціального мають пройти послідовні стадії. Г. Блумер виділяє п'ять стадій соціальної проблеми: виникнення, легітимація, (припускаємо, що перша та друга стадії становлять етап усвідомлення соціальної проблеми), мобілізація дій щодо іiі вирішення, формування офіційного плану дій, трансформація плану дій в його емпіричне здійснення (Blumer, 1971, с. 298-306; Фуллер, 2001, с. 138-141). Тому для оптимізації адресного здійснення соціальної роботи,перш за все, необхідно пройти процес ідентифікації соціальних проблем.

Маргіналізація згаданих соціальних груп $є$ феноменом сучасної соціальної реальності, який тісно пов'язаний із повсякденним життям. Через існування в часі війни поле соціальних проблем стало звичним та буденним соціальним знанням, що легітимується людьми, супроводжуються соціальними реакціями на різних рівнях. За допомогою медіа ці проблеми стали нашими реаліями, проте неналежним $\epsilon$ дотримання політик щодо здійснення ефективних заходів профілактики дискримінації. В той час, коли соціальні групи і їхні проблеми стали звичним явищем для нас, ми ще не можемо передбачити наслідків цих процесів і впливів на конкретних особистостей, але вже стикаємося із соціальною нетерпимістю до маргіналізованих груп.

Соціальна маргіналізація є актуальною темою суспільств різних часів. Поняття маргінальної особистості ввів у науковий обіг Р. Парк у 1928 році. Послідовниками Парка у США сформувався науковий підхід, за якого акцентується увага на культурному конфлікті, що виникає при переході з однієї соціальної спільноти до іншої, як чиннику формування маргінального типу особистості, яка перебуває на межі культур (Ципко, 2015, с. 150). Водночас, в основі поняття маргінальності $є$ процессоціальної декласації, що характеризуєтьсяпогіршенням соціального статусу людини,зниженням рівня життя, втратою професійнихнавичок, розривом соціальних зв'язків і зміноюсистеми цінностей, раніше властивих тому класу,до якого належала особистість (Лінгур, 2016, с. 34). Отже, маргінальність підкреслює певний соціальний статус (зазвичай низький), належність до меншості, що знаходиться на межі чи поза соціальною спільнотою, сповідує цінності й веде спосіб життя, що відрізняється від загальноприйнятої норми (Литвинчук, 2015, с. 52). 
Сьогодні під час здійснення профілактикимаргіналізації гостро стоїть потреба створювати позитивний досвід і портрет маргіналізованих груп у суспільстві, що не виконується в рамках здійснення соціальної політики. Наприклад, в контексті проблематизації військового стану можемо говорити не лише про негативну маргіналізацію, але й про позитивну маргіналізацію особистостей. Саме позитивна маргіналізація може бути одним з інструментів соціального включення різних категорій та груп. Водночас важливим $є$ питання стимулювання особистого волевиявлення і мотивації для зміни індивідами свого становища, оскільки їхнє соціальне виключення може бути спричинене своєрідною самомаргіналізацію внаслідок різних негативних факторів.

На процес внутрішніх змін представників цих категорій впливають безліч факторів, перш за все, це криза, пов'язана з періодом переходу (переміщення), від одного стану до іншого (Р.Парк, Е.Стонквіст та ін.). Значимість ситуації переходу, зміни соціального статусу осіб з кризових категорій визначається тривалістю вчасі та глибиною трансформації їхнього соціального середовища. Ще одним фактором $є$ невизначеністьсоціального становища цих осіб, виключність (або неповна включеність) в соціальні структури тагрупи. Цей фактор реалізується через труднощі у самоідентифікаціїіндивідів/груп при спробі самовіднесення до загальновизнаних, «нормативних» соціальнихоб'єднань чи груп (Ципко, 2015, с. 153-154).

Дослідження вивчення умов для створення змін слід здійснювати 3 аналізу стартових умов - умов «без змін», тобто зі стану рівноваги, в якій перебуває особа «тут і зараз». Вивчення цього аспекту дозволить визначити, що можна робити по-іншому i чи стануть «інші» (нові) процеси чи методи роботикритеріями чи передумовами змін (К. Левін / Little, 2013, p. 77). Стани рівноваги можуть бути змінені в будь-який з двох способів: шляхом додавання сил у потрібному напрямку, або шляхом зменшення протилежних сил (за теорією поля К. Левіна). Дуже часто система змін грунтується на ідеї «соціальної звички», для здійснення змін потрібна додаткова сила достатня для того, щоб «розірвати звичку», щоб «розморозити» звичай. Здійснити зміни і вплинути на індивіда значно простіше через здійснення безпосереднього впливу на соціальні групи, до якихвін належить.Зміна їхніх соціальних стандартів дозволяе зменшити тиск сили, яку прикладають для здійснення змін соціальної поведінки. Водночас, якщо опір особи заміниться частково на значення, яке має стандарт групи для окремої особи, то опір змінам має зменшуватися, якщо зменшується сила вартості стандарту групи.Тому, звичайно, легше здійснювати вплив/зміни на осіб, утворених у групу, ніж змінювати одну з них окремо. Індивід буде протистояти змінам настільки, наскільки він повинен відійти від стандартів групи. Якщо змінюється сам стандарт групи, то усувається чи зменшується опір, що 
обумовлений зв'язком між індивідуальним і груповим стандартом (Neweomb, 1947, pp. 340-44).

Опір це внутрішня перешкода для змін, в той же час,ще одним фактором i зовнішньою перешкодою $\epsilon$ соціальна напруга. Для зменшення соціальної напруги,зумовленою соціальною виключеністю,необхідно розвивати соціальну включеність представників маргіналізованих груп і активно залучати цих осіб до вирішення соціальних проблем на різних рівнях.

Окрім того, варто наголосити на тому, що слід розвивати комплекс навиків самодопомоги особистості. Адже, як бачимо, колективна чи кооперативна допомога, терапія, соціальна адаптація, тощо, не будуть ефективними без внутрішнього бажання і мотивації, тому відкритим залишається питання щодо факторів, які в тій чи іншій ситуації розвивають здатність до самозбереження i самовідновлення, сприяють внутрішнім змінам особистості, наснажують іiі i спонукають до розвитку психологічної стійкості.

В процесі роботи 3 маргіналізованими групами важливо працювати над установками, які сприяють розвитку і пошуку тих ресурсів, які необхідні для адаптації до нових умов. Не слід забувати, що соціальна маргіналізація першочергово породжується суспільством, але, водночас, цей процес є замкнутим у циклі, бо маргіналізовані групи часто самі встановлюють рамки i самі відкидають на маргінес осіб, які їх оточують. Отже, варто насамперед визначити, хто є об'єктами та суб'єктами маргіналізації, об'єктами та суб'єктами змін, а під час визначення підходу до роботи розподілити сфери діяльності в площині суб'єкт-суб' єктних зв'язків.

Звісно, в контексті здійснення соціальної роботи найперше маємо говорити про психологічну підтримку, відновлення, соціальних зв'язків, профорієнтацію та трудову адаптацію маргіналізованих груп. Деякі програми вже реалізовуються на державному рівні. Сьогодні можемо говорити пророботу муніципальних, державних установ, неурядових організацій тощо. На практиці вони лише розпочинають здійснювати роботу з даними групами населення. Агентами, які можуть забезпечити стартову площадку для таких впроваджень, рушійних змін та інновацій мають стати фахівці соціальної сфери, які є/можуть бути підтримкою для цих категорій і забезпечать організаційні процеси.

Сьогодні ми лише будуємо компетентний рівень підготовки фахівців, які можуть ефективно працювати 3 маргіналізованими категоріями. Часто фахівці мають невисокий рівень професійної підготовки, не розуміють соціальної ситуації клієнта, а технології роботи іноземного зразка можуть не відповідати національним реаліям, тому потребують постійної адаптації. Отже, досі актуальним є надання комплексної підтримки, допомоги і навчання для осіб, які працюють із зазначеними категоріями населення. 
Для роботи з маргіналізованими групами в соціальній сфері можна застосувати метод проектування у наданні соціальних послуг через аналіз ситуації клієнта, шляхом використання форм оцінки потреб особистості. Оскільки ми не можемо завжди розуміти життєві інтереси, потреби тої категорії осіб, з якою працюємо, великого значення набуваєглибинне дослідження біографічних історій, життєвих стратегій і пріоритетів особистостей, щоб зрозуміти їхнє бачення ситуації, яке слід вважати експертним.Водночас, маємо поставити питання про розширення критеріїв оцінки, стандартизації або комплексного визначення поняттєвих аспектів під час взаємодії з клієнтом, щоб з'ясувати, чи завжди ми ідентифікуємо із ним поняття однаково. Дослідження цих аспектів дозволить збудувати фахову соціальну підтримку на шляху до мотивації для змін.

Окрім внутрішніх змін особистості і іiі середовища, можемо говорити про зовнішні зміни, якіможуть бути реалізовані через систему інститутів. Цей аспект потребує детального викладу і глибинного дослідження, але попередньо можна сказати, що зовнішні зміни будуть здійснюватися через систему інститутів, зокрема через зміни хоча 6 в одному 3 них, адже зміна в єдиному соціальному інституті системи призводить до змін у всіх соціальних інститутах (Little, 2013, p. 77). Цей принцип можна виокремити під час дослідження інституційної підтримки надання соціальних послуг маргіналізованим групам на макрорівні.

Відповідно до рівнів суспільства, можна визначити рівні підтримки i організації роботи соціальних фахівців з маргіналізованими групами:

- Макрорівень - нормативна підтримка, регуляція і контроль за виконанням рішень урядових установ.

-- Мезорівень - локальна робота муніципальних служб (громади міста та ОТГ), залучення представників груп шляхом створення спільнотв просторі інституцій соціальної сфери.

- Мікрорівень - робота фахівцівз конкретними особистостями представниками спільнотта груп, найближчим оточенням; пошук представників спільнот для формування запиту і представництва інтересів.

Напрями організаційної роботи:

- Формування запиту: діагностика інтересів і потреб клієнтів, аналіз соціального середовища і внутрішньої соціальної ситуації, враховуючи соціокультурний контекст, соціальні норми, динаміку становища, конкретну ситуацію;узгодження інтерпретації понять.

- Здійснення комплексної інституційної і фахової підтримки: робота над створенням мережі установ за напрямом роботи, підготовки кваліфікованих кадрів.

- Формування ініціативи в середовищі маргіналізованої групи середпредставників груп, активне використання суб'єкт-суб' єктного 
підходу,методу «рівний-рівному», «живої книги» та ін.; залучення представників груп як експертівсоціальної ситуації.

- Визначення індивідуальних мотивів і формування установок, які будуть сприяти внутрішній трансформації $\mathrm{i}$ соціальним змінам в середовищі спільнот/груп.

\section{Висновки}

В дослідженні визначено підхід до організації соціальної роботи із маргіналізованими групами. Вказано, що процес змін здійснюється через внутрішні зміни, що характеризується впливом зміни соціального статусу осіб 3 кризових категорій, труднощами у їх самоідентифікації. Базовим процесом у соціальній роботі визначено вивчення стану рівноваги у житті індивіда (умов «без змін»), на який можна здійснювати вплив; та здійснення впливу на особистість через вплив на стандарти групи їі приналежності, що має зменшити внутрішній опір в процесі змін. Зовнішньою перешкодою для змін визначено соціальну напругу, яку можна подолати шляхом створення позитивного образу маргіналізованих груп (позитивна маргіналізація) і соціального включення осіб 3 кризових категорій до різних середовищ. Було запропоновано базові процеси для початкового рівня соціальної роботи $з$ маргіналізованими групами. Водночас, варто наголосити, що в контексті роботи з маргіналізованими групами варто відійти від структурованої моделі чи алгоритму роботи, де буде прописана чітка діяльність, а працювати гнучко, здійснювати соціальну роботу включено у середовище конкретної соціальної групи.

Перспективи подальших досліджень. Слід зазначити, що соціальні зміни в конкретній спільноті сьогодні можуть бути реалізовані через соціальні проекти, які мають бути укладені із врахуванням тих причин i мотивів, які будуть спонукати осіб до змін, а також здійснення конкретних дій. На дослідження мотивів і факторів змін, а також здійснення соціальних проектів, спрямованих на соціальні зміни в середовищі маргіналізованих груп, будуть спрямовані подальші наукові пошуки.

\section{Література}

Литвинчук, О. (2015). Маргіналізація українського суспільства. Наукові записки Національного університету “Острозька академія”. Серія: Філософія. Випуск 17. С. 51-55.

Лінгур, Л. \& Поліщук, С. (2016). Аналіз соціально-економічних факторів маргіналізації населення України. Економіка: реалії часу. №6(28). С. 33-39.

Олійников, Г. (2017). Психогенії та протиправна поведінка осіб із посттравматичними стресовими розладами, постраждалих у результаті 
антитерористичної операції. Актуальні проблеми вітчизняної юриспруденції. № 2. T. 2. C. $125-130$.

Фуллер, Р. \& Майерс, Р. (2001). Стадии социальной проблемы. Контексты современности. II : Хрестоматия. 2-е изд., перераб. и доп. ; [сост. и ред. С. Ерофеев]. Казань : Изд-во Казан. ун-та, С.138-141.

Ципко, С. \& Кріслата, Х. (2015). «Нові маргінальні групи» у соціальній структурі сучасного суспільства: теоретичний аспект дослідження. Релігія та соціум. №1-2 (17-18). С. 149-155.

Blumer, G. (1971). Social Problems as Collective Behavior, in Social Problems. Vol. 18. pp. 298-306.

Little, W. (2013). Introduction to Sociology - 1st Canadian Edition. Rice University. p. 707.

Neweomb, T. \& Hartley, E. (1947). Social Psychologyby. Co-Chairmen of Editorial Committee, Henry Holt and Co. P. 340-344. 


\title{
SOCIAL WORK WITH MARGINALIZED GROUPS: PLANNING AND ORGANIZING
}

\author{
Iryna Krynytska, Candidate of Sociology, Associate Professor of the Department of \\ Social Pedagogy, Lviv Catholic University, \\ Lviv, Ukraine.
}

\begin{abstract}
Ukraine has declared itself a social state, and therefore, has been gradually stabilizing the level of social protection of vulnerable population groups in the sphere of material provision. However, the problem of marginalization and social exclusion still remains largely unresolved.
\end{abstract}

The report identifies approaches to the organization of social work with marginalized groups and outlines the concept of marginalization as a process of social declassation of individuals. The major theoretical assumptions underlying this social research are the theory of social problems, the theory of change, motivation, social inclusion and exclusion.

The study argues that the process of internal changes is characterized by the impact of the change in the social status of persons belonging to the crisis-driven categories, difficulties in their self-identification. The research establishes the basic procedure for social work, which is the study of the state of the equilibrium of an individual's life (the "unchanging" circumstances), and transformation of a personality through the influences onto the standards of the group he \she fits in, which should reduce the resistance in the course of change. Social tension is defined as an external barrier to change, which can be overcome by the creation of the positive image of marginalized groups (positive marginalization) and social inclusion of people from crisis-bound categories into different environments.

The paper looks at the necessity to reinforce personal self-help skills, to form settings that contribute to the development and search for the resources necessary to adapt to new conditions.

The author stresses the importance of social service institutions and of the growth of competence of their specialists.

The concluding part suggests some support leverages in the fields of macro-, mesoand micro-levels of social work with marginalized populations, and directions for their implementation at the organizational level: filing a request; securing a complex institutional support; forming initiatives within the marginalized group; identifying individual motives and shaping settings that will contribute to internal transformation and social change in a community / group. 
Keywords: marginalization; social work; theory of changes; social exclusion; levels of social work support; directions of organizational work.

\section{References}

Lingur, L. \& Polischuk, S. (2016). Analysis of socio-economic factors of Ukraine's marking margination economics: realities of time. Economics: Realities of Time, 6 (28), 33-39.

Litvinchuk, O. (2015). Marginalization of Ukrainian Society. Scientific Notes of the National University of Ostroh Academy. Series: Philosophy, 17, 51-55.

Oliynykov, G. (2017). Psychogenic and illegal behavior of persons with posttraumatic stress disorder, victims of the antiterrorist operation. Actual problems of domestic jurisprudence, 2, 2, 125-130.

Fuller, R. \& Myers, R. (2001). The Stages of the Social Problem. Contexts of the Modern - II: Reading, 2, 138-141.

Tsipko, S. \& Krislata, H. (2015). New marginal groups»in the social structure of modern Ukrainian society:theoretical aspects ofresearch. Religion and society, 1-2 (1718), 149-155.

Blumer, G. (1971), Social Problems as Collective Behavior, in Social Problems, 18, 298-306.

Neweomb, T. \& Hartley, E. (1947). Social Psychologyby. Co-Chairmen of Editorial Committee, Henry Holt and Co., 340-344.

Little, W. \& McGivern, R. (2013) Introduction to Sociology - 1st Canadian Edition, Rice University, 707. 